\title{
Probabilistic Seismic Landslide Hazard Maps Including Epistemic Uncertainty Yubing Wang ${ }^{\mathrm{a} 1}$ and Ellen M. Rathje $\mathrm{a}^{\mathrm{a}^{*}}$
}

a University of Texas at Austin, Department of Civil, Architectural, and Environmental Engineering, 301 E. Dean Keeton St, Stop C1700, Austin, TX 78712, United States

1 Present address: Fugro Consultants, Inc., 8613 Cross Park Dr, Austin, TX 78754, United States

* Corresponding Author: Tel.: +1 5122323683

Fax: +1 5124716548

E-mail address: e.rathje@mail.utexas.edu

Other author email addresses: $\quad$ wangyubing1987@ hotmail.com 


\title{
Probabilistic Seismic Landslide Hazard Maps Including Epistemic Uncertainty
}

\begin{abstract}
Seismic landslide hazard maps are used in regional planning to identify zones that require detailed, site-specific studies. Most seismic landslide hazard maps are based on predicted sliding block displacements for a given level of shaking, but this deterministic approach does not fully consider the aleatory variability in the sliding displacement prediction or the epistemic uncertainty in the soil and slope properties. Probabilistic approaches incorporate aleatory variability through a sliding displacement hazard curve and they incorporate epistemic uncertainties (e.g., soil shear strength, empirical displacement model) through a logic-tree approach. This fully probabilistic approach can be implemented efficiently on a regional scale for seismic landslide hazard maps using ground motion hazard data and the Mean $\lambda_{\mathrm{D}}$ Threshold approach. This paper applies the probabilistic approach to develop a seismic landslide hazard map for Anchorage, Alaska. The results show that incorporating epistemic uncertainty can increase the area of high seismic landslide hazard by a factor of 2 to 3 as compared to analyses without any epistemic uncertainty. Additionally, incorporating a logic-tree avoids using overly conservative input parameters in a deterministic approach to capture these uncertainties, which can lead to an unrealistic inflation of the seismic landslide hazard.
\end{abstract}

Keywords: Seismic landslide hazard mapping, seismic slope stability, logic tree 


\subsection{INTRODUCTION}

Seismic landslide hazard maps are used by various government agencies to identify zones that are prone to earthquake-induced slope failures and therefore require detailed, site-specific studies. Often these seismic landslide hazard maps (e.g., Jibson et al. 2000, McCrink 2001) evaluate the potential for seismic slope failures through predictions of sliding displacement for the expected ground shaking and general slope properties. The seismic landslide hazard is assigned qualitatively as very high to low based on the predicted level of displacement relative to prescribed displacement thresholds Typically, these maps are generated using a deterministic approach that does not consider the aleatory variability in the predictions of sliding displacement; nor do they consider the epistemic uncertainty in the slope properties (e.g., soil shear strengths, ground water table location, and thickness of sliding blocks) or the empirical predictive models for displacement.

An example of a recently developed seismic landslide map is shown in Figure 1 (Jibson and Michael 2009). This map for Anchorage, Alaska is based on deterministic estimates of displacements computed from the expected peak ground acceleration at $2 \%$ probability of exceedance in 50 years. The map identifies areas of low to very high seismic landslide hazard based on the computed displacements relative to the displacement thresholds indicated. Although this mapping approach represents a significant improvement over approaches used previously (e.g., the ground motion is derived from probabilistic seismic hazard analysis, a robust displacement model is used), it still has limitations. For example, the displacement prediction does not account for displacement variability, only a single displacement model is used to predict displacement, best-estimate soil properties are used to calculate the yield acceleration, and a single assumed value of water table depth is used in the analyses. 


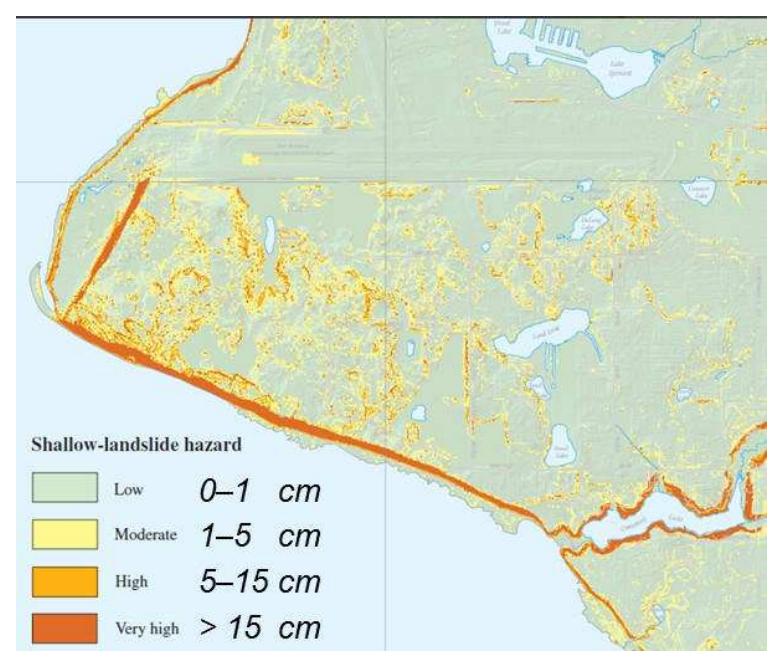

Figure 1. Deterministic seismic landslide hazard map for $2 \%$ probability of exceedance in 50 years for Anchorage, Alaska (Jibson and Michael 2009)

Rathje and Saygili (2008) proposed a probabilistic approach that uses a sliding displacement hazard curve to define the seismic landslide hazard. A displacement hazard curve combines a ground motion hazard curve with the aleatory variability in the sliding displacement prediction to compute the annual frequency of exceedance (i.e., hazard) of different displacement levels. It then can be used to identify the probabilistic displacement associated with the hazard level of interest. Using the displacements associated with the hazard level of interest (typically $10 \%$ or $2 \%$ probability of exceedance in 50 years), a seismic landslide hazard map is produced using the same displacement thresholds used in the deterministic approach (Saygili and Rathje 2009). An attractive characteristic of this fully probabilistic approach is that it makes uses of the results from an independently computed ground motion hazard study and thus decouples the seismic landslide analysis from the ground motion hazard analysis.

This probabilistic approach accounts for the variability in the displacement prediction but does not account for epistemic uncertainties associated with various components of the analysis. Monte Carlo simulations have been used to account for these uncertainties in seismic landslide 
studies (e.g., Refice and Capolongo 2002) but they require a large number of simulations, which may be difficult for regional studies. Alternatively, a logic tree can be used to efficiently account for epistemic uncertainties. A logic tree identifies different possible values of input parameters or different alternative models and weights are assigned to each value/model based on the relative belief in their accuracy. Although the values and weights assigned to a logic tree are somewhat subjective and two analysts may assign different values/weights, the logic tree acknowledges and accounts for other possible parameter values/models as opposed to deterministic analysis where all weight is put on a single set of parameter values/models.

For seismic slope stability problems, the uncertain input parameters are those associated with the slope properties and the alternative models are those associated with the sliding displacement prediction. Logic trees have become standard practice for accounting for epistemic uncertainty in probabilistic seismic hazard analyses for ground shaking (e.g., Bommer and Scherbaum 2008). When applied to probabilistic seismic landslide hazard assessment, hazard curves are computed for each set of inputs/models and a weighted mean hazard curve is computed from the individual hazard curves and their associated weights (Rathje and Saygili 2009). This weighted mean hazard curve for seismic landslide displacement is used to assign the seismic landslide hazard. It is important to note that the epistemic uncertainties associated with the ground motion hazard are not included in logic tree for seismic landslide analysis because they have already been taken into account in the ground motion hazard analysis.

Despite its efficiency over Monte Carlo simulations, the direct application of the logictree approach can still be very time-consuming for regional mapping of seismic landslide hazards. An efficient computational scheme, called the Mean $\lambda_{\mathrm{D}}$ Threshold approach, was recently proposed that allows a logic tree to be applied more easily to regional analysis (Wang 
and Rathje 2014). The Mean $\lambda_{\mathrm{D}}$ Threshold approach can rigorously incorporate variability and uncertainty into seismic landslide hazard mapping without significantly increasing the computational complexity compared with the deterministic approach.

This paper describes the components required to perform a probabilistic seismic landslide assessment that includes the effects of epistemic uncertainty through the use of the logic tree. The Mean $\lambda_{\mathrm{D}}$ Threshold approach, which allows the logic-tree analysis to be applied efficiently at regional scale to develop seismic landslide hazard maps, is introduced. The approach is applied to a study area around Anchorage, Alaska. The procedures and data used to develop the ground motion data and logic tree are described. The resulting seismic landslide hazard maps are compared with available deterministic maps, and are used to investigate the influence of different sources of uncertainty on the seismic landslide hazard.

\subsection{Components of Probabilistic Seismic LANDSLide ASSESSMent}

\subsection{Yield Acceleration}

The resistance of a slope to sliding under seismic conditions is characterized by the yield acceleration $\left(\mathrm{k}_{\mathrm{y}}\right)$. The yield acceleration is defined as the acceleration that results in a factor of safety of 1.0 for the slope, and accelerations greater than $\mathrm{k}_{\mathrm{y}}$ induce sliding. In regional analysis, an infinite slope model is commonly used to compute the yield acceleration (e.g., Jibson et al. 2000). This approach is justified because as much as $90 \%$ of earthquake-induced landslides are shallow slides and falls (Keefer 2002, Jibson 2011). Using the infinite slope analysis to predict the static factor of safety of the slope $\left(F S_{\text {static }}\right)$ and assuming ground shaking parallel to the slope, the yield acceleration can be calculated as (Newmark 1965):

$$
F S_{\text {static }}=\frac{c^{\prime}}{\gamma \sin \alpha}+\frac{\tan \phi^{\prime}}{\tan \alpha}\left(1-m \frac{\gamma_{w}}{\gamma}\right)
$$




$$
k_{y}=\left(F S_{\text {static }}-1\right) g \cdot \sin \alpha
$$

where $\mathrm{g}$ is the acceleration of gravity, $\alpha$ is the slope angle, $\mathrm{c}^{\prime}$ is the effective cohesion, $\phi^{\prime}$ is the effective friction angle, $\gamma$ is the material unit weight, $\gamma_{\mathrm{w}}$ is the unit weight of water, $t$ is the slopenormal thickness of the rigid block, and $m$ is the proportion of the block thickness that is saturated and thus represents pore water pressure.

The input parameters for the $\mathrm{k}_{\mathrm{y}}$ calculation (e.g., slope angle, shear strength) take on different values at different locations across a study area. In a Geographic Information System (GIS), such location-dependent data are stored as raster data with grid cell sizes typically on the order of meters for regional landslide analysis. An entire study area can be divided into millions of grid cells. A Digital Elevation Model (DEM), which contains the elevation at the center of each grid cell, is used to compute the slope angle of each grid cell. The required shear strength data are assigned different geologic units, and the parameters $\gamma, t$, and $m$ generally are assumed and assigned constant values across a study area (Jibson et al. 2000).

\subsection{Sliding Block Displacements}

Newmark (1965) proposed a rigid sliding block analysis for assessing the displacement and failure of slopes during earthquakes. In this approach, accelerations greater than the yield acceleration generate downslope movement. In the United States, both the United States Geological Survey (USGS) and the California Geological Survey (CGS) have adopted the rigid sliding block method as the basis for seismic landslide hazard mapping (e.g., Jibson et al. 2000, McCrink 2001). Sliding block analysis requires the yield acceleration of a slope and the acceleration-time history at a site. Because of the variable nature of earthquake ground motions, a suite of at least 7 to 10 acceleration-time histories are commonly used for analysis. However, 
the identification, selection, and scaling of appropriate acceleration-time histories is a difficult and time-consuming process for regional analysis. Instead of directly using acceleration-time histories to predict rigid sliding block displacements, many empirical models have been proposed for computing sliding block displacements using the characteristics of ground shaking and the yield acceleration. These empirical displacement models are from the regression analysis of thousands of displacements computed from different acceleration-time histories and yield accelerations.

The general form of an empirical displacement model is expressed as:

$$
\ln (D)=f\left(k_{y}, G M s\right)
$$

The natural logarithm of the displacement (D) is predicted as a function of the yield acceleration and various ground motion parameters (GMs). To be used in a probabilistic analysis, the empirical model must also include an associated aleatory variability $\left(\sigma_{\operatorname{lnD}}\right)$. Various ground motion parameters, such as Peak Ground Acceleration (PGA), Peak Ground Velocity (PGV), and Arias Intensity $\left(\mathrm{I}_{\mathrm{a}}\right)$, have been used individually or in combination to represent ground shaking in empirical displacement models. Bray and Travasarou (2007, BT07), Jibson (2007, J07), and Rathje and Saygili (2009, RS09) proposed empirical displacement models for rigid sliding masses that use PGA and earthquake magnitude (M) to characterize the ground shaking. Saygili and Rathje (2008, SR08) proposed a rigid sliding block model using PGA and PGV as the ground motion parameters, and Jibson (2007) proposed a model using PGA and $\mathrm{I}_{\mathrm{a}}$. Empirical displacement models that use more than one ground motion parameter typically have smaller 
standard deviations (i.e., variability) than those that include only one ground motion parameter (Saygili and Rathje 2008).

The displacements computed by empirical models are not exact predictions of measureable displacements, but rather indicate the likelihood of continuing deformation and the occurrence of landslides. Therefore, larger displacements represent a higher probability of landslide occurrence (Jibson et al. 2000). The displacement thresholds currently used by the USGS (Jibson and Michael 2009) for its seismic landslide maps are shown in Table 1.

Table 1. Seismic landslide hazard categories

\begin{tabular}{|c|c|}
\hline Hazard Category & Sliding Displacement $(\mathrm{cm})$ \\
\hline Low & $0-1$ \\
\hline Moderate & $1-5$ \\
\hline High & $5-15$ \\
\hline Very High & $>15$ \\
\hline
\end{tabular}

\subsection{Earthquake Ground Motions}

The ground motion parameters required by the empirical displacement models are obtained from seismic hazard curves that may come from site-specific probabilistic seismic hazard analysis (PSHA) or from the USGS (http://geohazards.usgs.gov/hazardtool/, Petersen et al. 2008). A PGA hazard curve provides a seismic hazard level (i.e., annual frequency of exceedance) for different values of PGA. The two most commonly used hazard levels are 0.0021 1/year (i.e., $10 \%$ probability of exceedance in 50 years) and 0.0004 1/year (i.e., $2 \%$ probability of exceedance in 50 years). Current deterministic mapping approaches simply use the ground motion at a given hazard level along with the $\mathrm{k}_{\mathrm{y}}$ within each grid cell to predict the median displacement from an empirical displacement model for that grid cell. The predicted 
displacement is compared with the displacement thresholds in Table 1 to assign the cell to the appropriate landslide hazard category.

\subsection{Displacement Hazard Curve}

Displacement hazard curves incorporate the aleatory variability in the displacement prediction and can provide a better assessment of hazard levels for seismic slope performance. A displacement hazard curve computes the seismic hazard level (i.e. mean annual rate of exceedance) for different levels of sliding displacement (i.e. slope performance). If the empirical displacement model is a function of PGA and M, the mean annual rate of exceedance $\left(\lambda_{\mathrm{D}}\right)$ for a displacement level $\mathrm{x}$ is computed as (Rathje and Saygili 2009):

$$
\lambda_{\mathrm{D}}(\mathrm{x})=\sum_{\mathrm{i}} \sum_{\mathrm{k}} \mathrm{P}\left[\mathrm{D}>x \mid \mathrm{PGA}_{\mathrm{i}}, \mathrm{M}_{\mathrm{k}}\right] \cdot \mathrm{P}\left[\mathrm{PGA}_{\mathrm{i}}, \mathrm{M}_{\mathrm{k}}\right]
$$

where $\mathrm{D}$ is sliding displacement, $\mathrm{P}\left[\mathrm{D}>x \mid \mathrm{PGA}_{\mathrm{i}}, \mathrm{M}_{\mathrm{k}}\right]$ is the probability of $\mathrm{D}>\mathrm{x}$ given the occurrence of acceleration level $\mathrm{PGA}_{\mathrm{i}}$ and earthquake magnitude $\mathrm{M}_{\mathrm{k}}$, and $\mathrm{P}\left[\mathrm{PGA}_{\mathrm{i}}, \mathrm{M}_{\mathrm{k}}\right]$ is the joint annual probability of occurrence of $\mathrm{PGA}_{\mathrm{i}}$, and $\mathrm{M}_{\mathrm{k}}$. These probabilities are computed from the ground motion hazard curve and the seismic hazard deaggregation in terms of magnitude and distance (Bradley 2010, Wang 2014).

If the empirical displacement model is a function of multiple ground motion parameters, a vector hazard approach is required (Bazzurro and Cornell 2002, Rathje and Saygili 2008). For a displacement model that uses PGA and PGV the mean annual rate of exceedance $\left(\lambda_{\mathrm{D}}\right)$ for a displacement level $\mathrm{x}$ is computed as (Saygili and Rathje 2009): 


$$
\lambda_{\mathrm{D}}(\mathrm{x})=\sum_{\mathrm{i}} \sum_{\mathrm{j}} \mathrm{P}\left[\mathrm{D}>x \mid \mathrm{PGA}_{\mathrm{i}}, \mathrm{PGV}\right] \cdot \mathrm{P}\left[\mathrm{PGA}_{\mathrm{i}}, \mathrm{PGV}_{\mathrm{j}}\right]
$$

where $\mathrm{P}\left[\mathrm{D}>x \mid \mathrm{PGA}_{\mathrm{i}}, \mathrm{PGV}_{\mathrm{j}}\right]$ is the probability of $\mathrm{D}>\mathrm{x}$ given ground motion levels $\mathrm{PGA}_{\mathrm{i}}$ and $\mathrm{PGV}_{\mathrm{j}}$, and $\mathrm{P}\left[\mathrm{PGA}_{\mathrm{i}}, \mathrm{PGV}_{\mathrm{j}}\right]$ is the joint annual probability of occurrence of ground motion levels $\mathrm{PGA}_{\mathrm{i}}$ and $\mathrm{PGV}_{\mathrm{j}} . \mathrm{P}\left[\mathrm{PGA}_{\mathrm{i}}, \mathrm{PGV}_{\mathrm{j}}\right]$ can be computed using a vector probabilistic seismic hazard analysis or derived from the PGA hazard curve, associated seismic hazard deaggregation for PGA, ground motion prediction equations for PGA and PGV, and the correlation coefficient between PGA and PGV (Bazzurro 1998, Rathje and Saygili 2009, Wang 2014). The correlation coefficient ( $\rho$ ) between PGA and PGV has been estimated as 0.6 (Rathje and Saygili 2008, Baker 2007).

Figure 2a shows the PGA ground motion hazard curve for the study area of Anchorage, Alaska, and Figure $2 \mathrm{~b}$ shows the displacement hazard curves for $\mathrm{k}_{\mathrm{y}}=0.1 \mathrm{~g}$ computed using the Anchorage hazard curve and two different empirical displacement models: the (PGA, M) displacement model of Rathje and Saygili (2009) and the (PGA, PGV) displacement model of Saygili and Rathje (2008). The different displacement models predict different displacements and therefore generate different displacement hazard curves. These differences represent epistemic uncertainty in the displacement prediction and are not currently taken into account in seismic landslide hazard assessment.

For comparison, the deterministic displacement for the (PGA, M) model is computed using the $2 \%$ in 50 year PGA of $0.61 \mathrm{~g}$, the mean $\mathrm{M}$ of 6.7 from the hazard disaggregation, and $\mathrm{k}_{\mathrm{y}}=0.1 \mathrm{~g}$. This deterministic displacement from the (PGA, M) model is $55 \mathrm{~cm}$, yet the probabilistic displacement from the scalar (PGA, M) model associated with a $2 \%$ probability of 
exceedance in 50 years (Figure 2b) is $164 \mathrm{~cm}$. This larger displacement is a result of incorporating the variability in the displacement prediction.

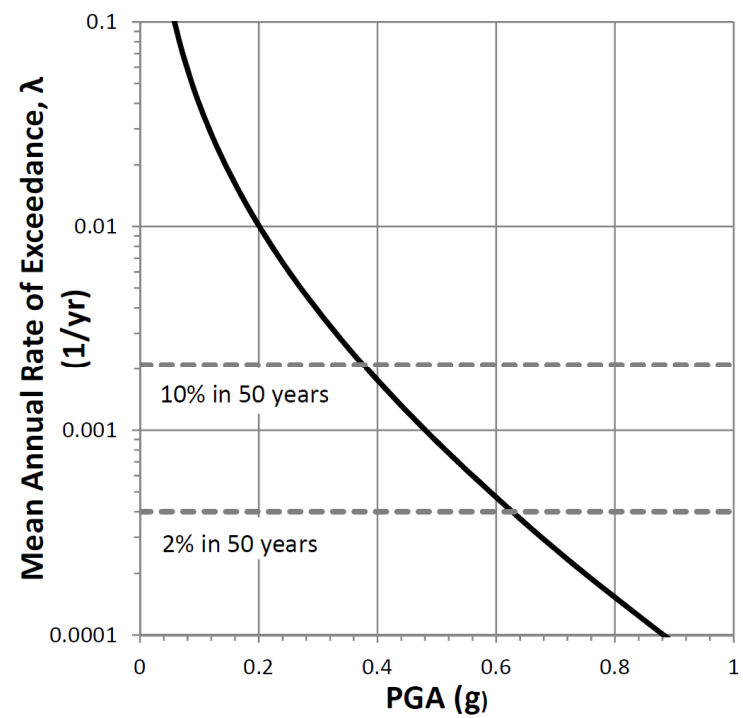

(a)

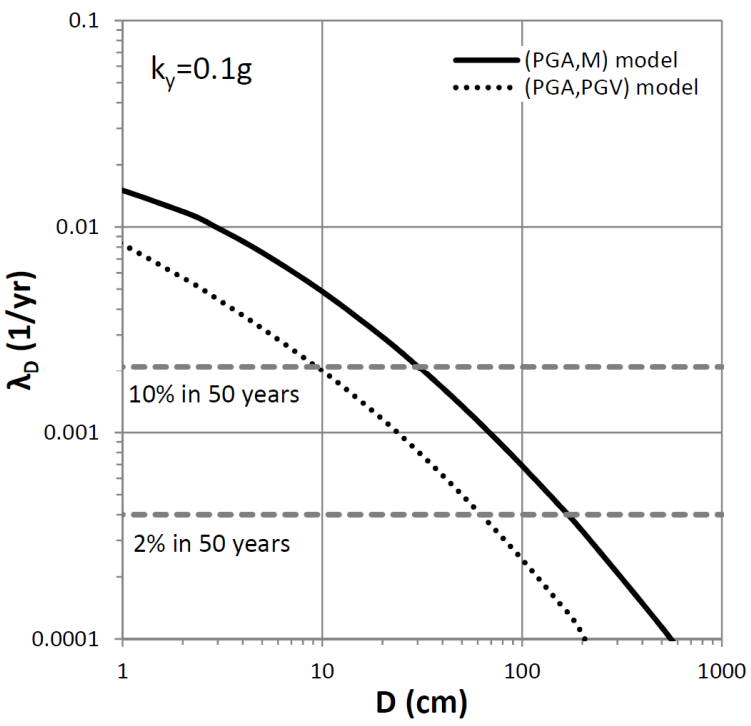

(b)

Figure 2. (a) PGA hazard curve for Anchorage, Alaska from the USGS (Petersen et al. 2008) and (b) displacement hazard curves for different displacement models and $\mathrm{k}_{\mathrm{y}}=0.1$.

\subsection{Logic-Tree Analysis}

Uncertainties always exist when characterizing slope properties (e.g., $c^{\prime}, \phi^{\prime}, \mathrm{t}$, and $\mathrm{m}$ ) for a slope stability analysis. Ignoring these epistemic uncertainties and assuming a single set of slope properties leads to a single value of $\mathrm{k}_{\mathrm{y}}$ for each grid cell, which simplifies the computation of the sliding displacement of the slope but does not account for the important uncertainties inherent in the analysis. Additionally, spatial variability of strength properties within a geologic unit can play an important role in the occurrence of landslides (Dreyfus et al. 2013), but is not often taken into account.

A logic-tree analysis can be used to account for epistemic uncertainties in the assessment of seismic landslide hazard potential (Saygili 2008, Rathje and Saygili 2009). A logic tree is made of nodes and branches, as illustrated in Figure 3a. Nodes represent the input parameters or 
models under consideration and the branches associated with a node represent discrete, possible values for that parameter or model and its associated weight. The logic-tree shown in Figure $3 \mathrm{a}$ for seismic slope stability includes nodes associated with the shear strength, the sliding block properties, and the empirical displacement models. Following branches through each node defines the set of input parameters for calculation of a displacement hazard curve. The branches related to shear strength and sliding block properties are used together to define a single $\mathrm{k}_{\mathrm{y}}$ value and the product of the weights of the branches represents the weight associated with that $\mathrm{k}_{\mathrm{y}}$. This $\mathrm{k}_{\mathrm{y}}$ is used along with an empirical displacement model and the ground motion hazard to compute a displacement hazard curve. For the logic tree in Figure 3a, the sections associated with shear strength and sliding block properties produce $54 \mathrm{k}_{\mathrm{y}}$ values for each grid cell and combined with the section of the logic tree associated with the empirical displacement models, a total of 216 displacement hazard curves are computed for each grid cell. The weight associated with each displacement hazard curve is the product of all of the weights associated with the input parameters/models used to calculate the hazard curve.

A mean displacement hazard curve is calculated from the multiple hazard curves and their weights as:

$$
\overline{\lambda_{D}}(x)=\sum_{i=1}^{n} w_{i} \cdot \lambda_{D}(x)_{i}
$$

where $\overline{\lambda_{D}}(\mathrm{x})$ is the weighted mean annual rate of exceedance for displacement $\mathrm{x}, \lambda_{\mathrm{D}}(\mathrm{x})_{\mathrm{i}}$ is the displacement hazard from the $\mathrm{i}^{\text {th }}$ branch of the logic tree for displacement $\mathrm{x}$, and $\mathrm{w}_{\mathrm{i}}$ is the weight associated the $\mathrm{i}^{\text {th }}$ branch of the logic tree. 


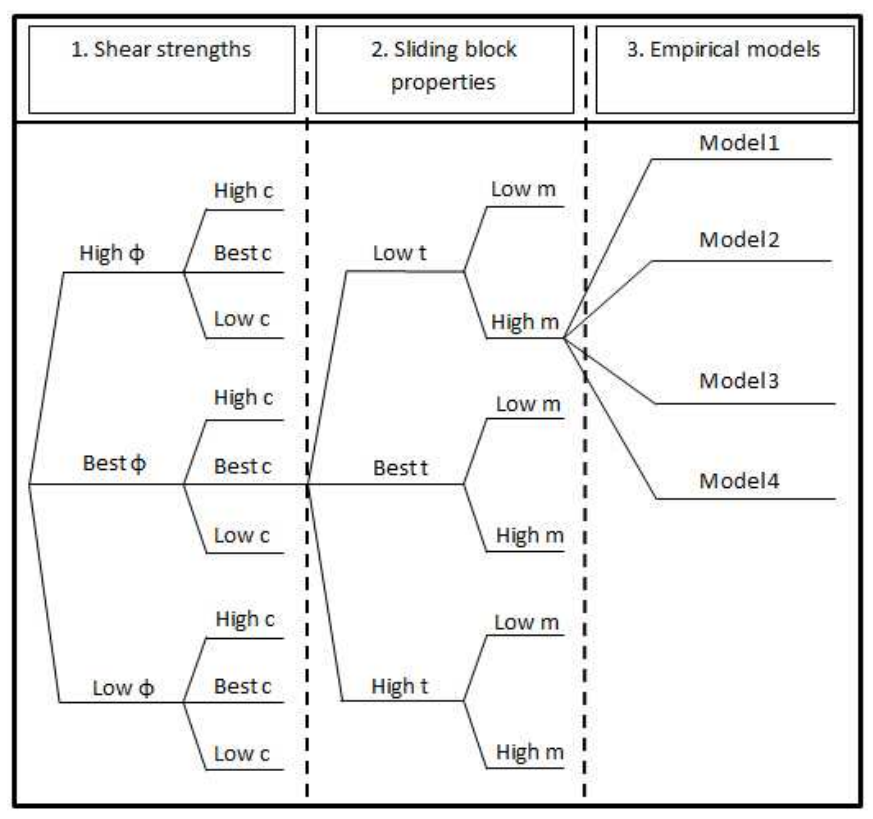

(a)

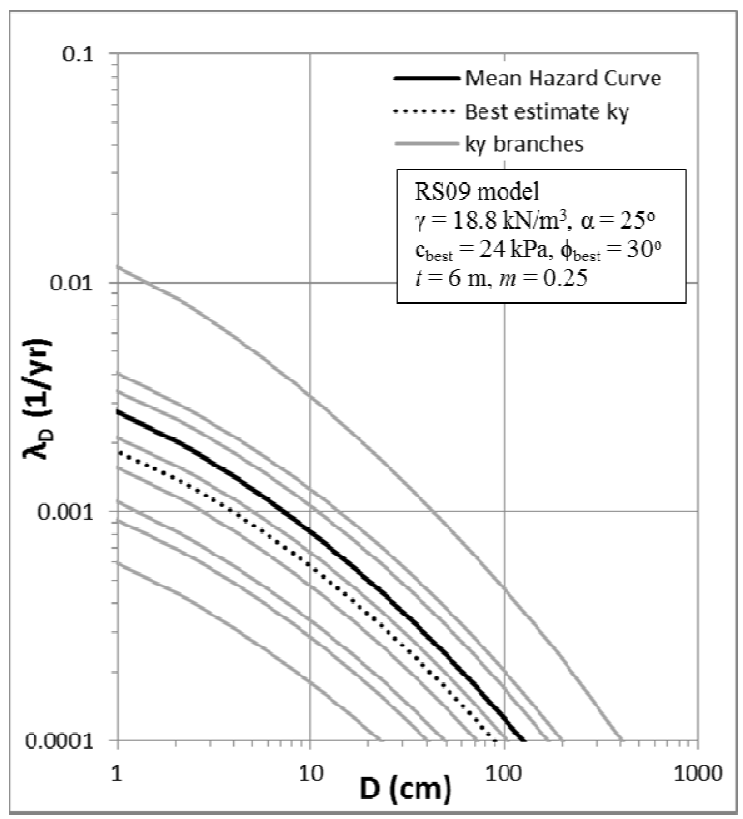

(b)

Figure 3. (a) Logic tree and (b) associated displacement hazard curves associated with the shear strength section of the logic tree.

To illustrate the calculation of the mean hazard curve, a slope with $\alpha=25^{\circ}, \mathrm{c}^{\prime}=24 \mathrm{kPa}$, $\square^{\prime}=30^{\circ}, \mathrm{t}=6 \mathrm{~m}, \mathrm{~m}=0.25$, and $\gamma=18.8 \mathrm{kN} / \mathrm{m}^{3}$ is considered along with the ground motion hazard in Anchorage. Assuming that the best-estimate properties represent mean values, the uncertainty in the shear strength is modeled through a logic tree with coefficients of variation (COV) of $20 \%$ for $\mathrm{c}^{\prime}$ and $10 \%$ of $\phi^{\prime}$ (Wang 2014). Figure $3 \mathrm{~b}$ shows displacement hazard curves computed for the 9 branches associated with the shear strength section of the logic tree. Also shown is the mean displacement hazard curve and the displacement hazard curve associated with the best-estimate $\mathrm{k}_{\mathrm{y}}$, (i.e., $\mathrm{k}_{\mathrm{y}}$ associated with the best-estimate shear strength). The mean displacement hazard curve predicts larger displacements than the hazard curve associated with the best-estimate $\mathrm{k}_{\mathrm{y}}$, demonstrating that the inclusion of epistemic uncertainty into the analysis increases the seismic landslide hazard. 


\subsection{ImPLEMENTING LOGIC-TREe ANALysis INTO REgional SEISMIC LANDSLIDE HAZARD}

\section{MAPPING}

When a logic-tree analysis is incorporated into regional mapping of seismic landslide hazard potential, each grid cell has dozens of possible $\mathrm{k}_{\mathrm{y}}$ values with associated weights. The rigorous approach to assigning a cell to a seismic landslide hazard category involves calculating a hazard curve for each $\mathrm{k}_{\mathrm{y}}$ and then computing the mean displacement hazard curve. This approach is computationally intensive because a region may have millions of grid cells. An efficient computational scheme has been developed to assign grid cells to a seismic landslide hazard category without sacrificing any accuracy and a screening procedure also is used to further enhance the efficiency (Wang and Rathje 2014). These approaches are outlined below.

\subsection{Efficient Computational Scheme}

When assigning a seismic landslide hazard category using a mean hazard curve, the target hazard level $\left(\lambda^{*}\right)$ is specified and the displacement associated with $\lambda^{*}$ is compared with the displacement thresholds (Table 1) to assign the appropriate hazard category. The efficient computation scheme, called the Mean $\lambda_{\mathrm{D}}$ Threshold approach, makes use of fact that to assign a seismic hazard category to a grid cell, $\overline{\lambda_{\mathrm{D}}}(\mathrm{x})$ only needs to be computed at the displacement thresholds. Comparing $\overline{\lambda_{D}}(\mathrm{x})$ for each displacement threshold with the target hazard level under consideration allows each grid cell to be assigned to an appropriate seismic landslide hazard category. The basis for this approach is illustrated in Figure 4. The mean hazard curve in Figure 4 indicates the sliding displacement is $8 \mathrm{~cm}$ at $\lambda^{*}=0.00211 / \mathrm{yr}$ and, therefore, this grid cell should be categorized as high seismic landslide hazard $(5 \mathrm{~cm}<\mathrm{D}<15 \mathrm{~cm}$, Table 1). The same 
conclusion can be obtained by comparing $\lambda^{*}=0.00211 / \mathrm{yr}$ with $\overline{\lambda_{\mathrm{D}}}(\mathrm{x})$ for the displacement thresholds of $x=5 \mathrm{~cm}$ and $x=15 \mathrm{~cm}$ (i.e., $\overline{\lambda_{D}}(5 \mathrm{~cm})$ and $\left.\overline{\lambda_{D}}(15 \mathrm{~cm})\right)$. If $\overline{\lambda_{D}}(5 \mathrm{~cm})$ is larger than $\lambda^{*}=0.00211 / \mathrm{yr}$, then the sliding displacement associated with $\lambda^{*}$ is larger than $5 \mathrm{~cm}$. If $\overline{\lambda_{\mathrm{D}}}(15 \mathrm{~cm})$ is less than $\lambda^{*}=0.00211 / \mathrm{yr}$, then the sliding displacement associated with $\lambda^{*}$ is smaller than $15 \mathrm{~cm}$. As a result, this grid cell is placed in the 5 to $15 \mathrm{~cm}$ bin (i.e., high seismic landslide hazard category) although the exact displacement value associated with $\lambda^{*}=0.0021$ 1/yr remains unknown. This is acceptable because only hazard categories, not exact predictions of sliding displacement, are required to create a seismic landslide hazard map.

The efficient application of the Mean $\lambda_{\mathrm{D}}$ Threshold approach to each grid cell involves rapid computation of $\overline{\lambda_{\mathrm{D}}}(\mathrm{x})$ from Equation (5) for each displacement threshold. Equation (5) utilizes the $\lambda_{\mathrm{D}}(\mathrm{x})$ values associated with each $\mathrm{k}_{\mathrm{y}}$ value from the logic tree. An interpolation relationship between $\lambda_{\mathrm{D}}(\mathrm{x})$ and $\mathrm{k}_{\mathrm{y}}$ is used for this purpose. The relationship between $\lambda_{\mathrm{D}}(\mathrm{x})$ and $\mathrm{k}_{\mathrm{y}}$ is a function of the ground motion hazard curve, the empirical displacement relationships, and the threshold displacement level (i.e., $\mathrm{x}$ ) under consideration. Thus, separate interpolation relationships must be developed for each threshold displacement level and displacement relationship given the ground motion hazard curve for the study area. The interpolation relationship is developed from a suite of displacement hazard curves computed for a range of $\mathrm{k}_{\mathrm{y}}$ values for a single threshold displacement level, a single empirical displacement model, and a single ground motion hazard curve, as illustrated in Figure 5. For example, considering a displacement threshold of $x=5 \mathrm{~cm}, \lambda_{\mathrm{D}}(5 \mathrm{~cm})$ is compiled from the displacement hazard curves for the given displacement model (Figure 5a) and plotted versus the associated $\mathrm{k}_{\mathrm{y}}$ (Figure 5b). $\lambda_{\mathrm{D}}(\mathrm{x})$ varies smoothly with $\mathrm{k}_{\mathrm{y}}$ and can be adequately fit with a polynomial relationship in log-log space (Figure $5 b$ ). This relationship is used to quickly calculate $\lambda_{\mathrm{D}}(5 \mathrm{~cm})$ for a given $\mathrm{k}_{\mathrm{y}}$ value. 


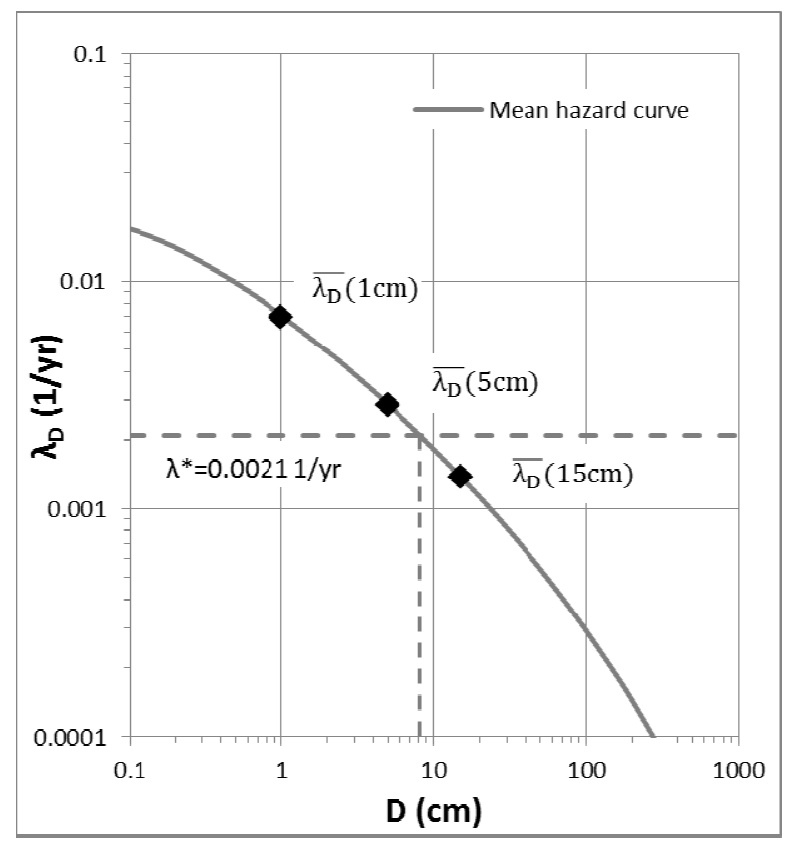

Figure 4. Illustration of Mean $\lambda_{\mathrm{D}}$ Threshold approach
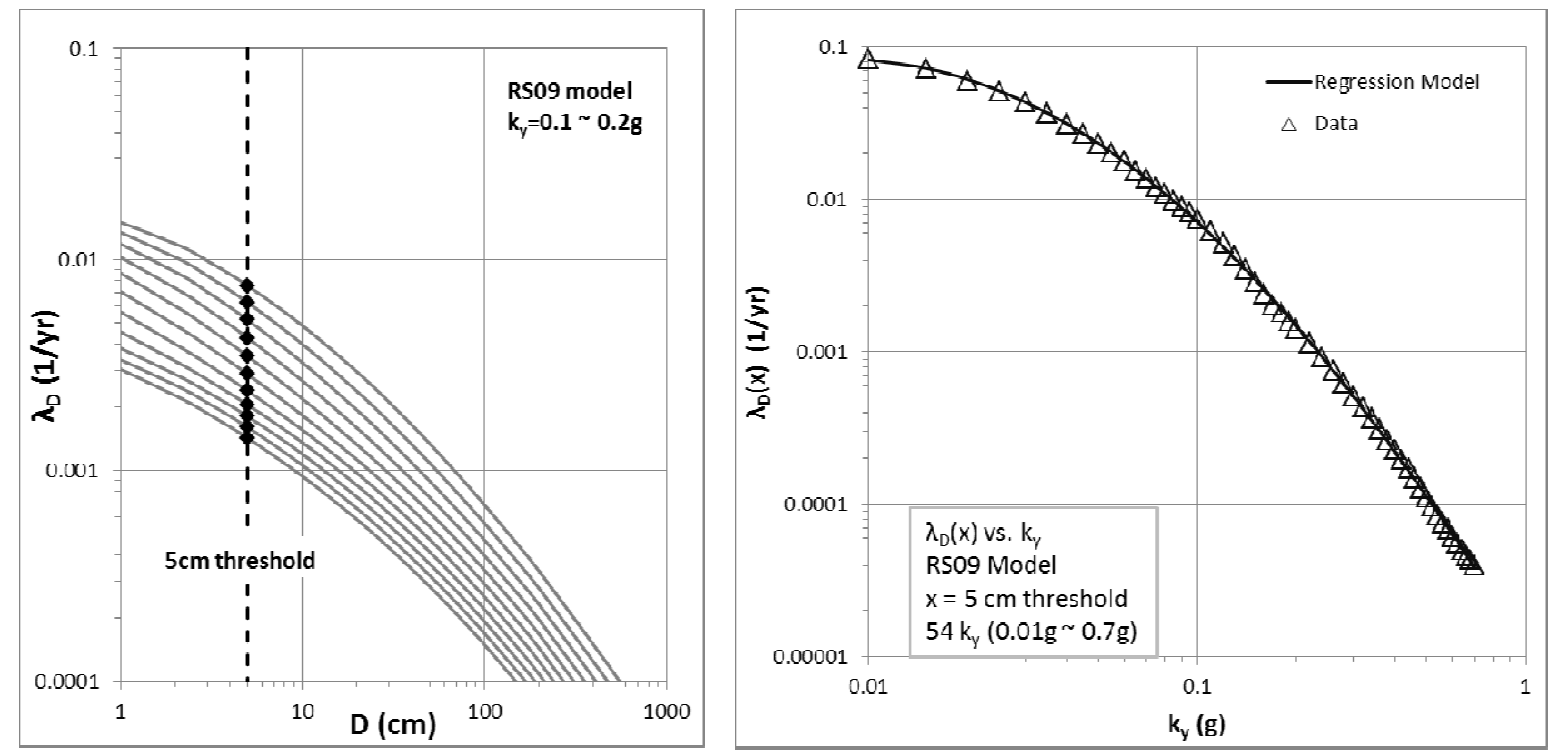

Figure 5. (a) Displacement hazard curves for $k_{y}$ values between 0.1 and $0.2 \mathrm{~g}$, (b) $\lambda_{\mathrm{D}}(\mathrm{x})$ vs. $\mathrm{k}_{\mathrm{y}}$ for $\mathrm{x}=5 \mathrm{~cm}$ and $\mathrm{k}_{\mathrm{y}}$ values between 0.01 and $0.7 \mathrm{~g}$.

The range of $\mathrm{k}_{\mathrm{y}}$ values of slopes that are potentially unstable during earthquakes can be estimated as 0.01 to $0.70 \mathrm{~g}$. Any slope with $\mathrm{k}_{\mathrm{y}}$ below $0.01 \mathrm{~g}$ is essentially statically unstable (FS 
1.0) and slopes with $\mathrm{k}_{\mathrm{y}}$ larger than $0.70 \mathrm{~g}$ are either very flat or are made of strong materials, meaning that such slopes can be assumed as seismically stable. Using a small $\mathrm{k}_{\mathrm{y}}$ increment and assuming all $\mathrm{k}_{\mathrm{y}}$ values are between 0.01 to $0.70 \mathrm{~g}$, there are only several dozens of possible $\mathrm{k}_{\mathrm{y}}$ values to consider within a study area, despite the presence of millions of grid cells. Therefore several dozen displacement hazard curves along with an interpolation between these hazard curves can be used to approximate all possible displacement curves in a region.

\subsection{Screening Analysis}

To further reduce the computation time for the regional analysis incorporating epistemic uncertainties, a screening analysis using the worst-case scenario of the logic tree is carried out. The worst-case scenario is associated with the minimum $\mathrm{k}_{\mathrm{y}}$ in the logic tree, which is associated with the smallest shear strength and the largest $m$ and $t$ values. This analysis highlights the grid cells that have low seismic landslide potential by evaluating if $\lambda_{D}(1 \mathrm{~cm})$ is less than $\lambda^{*}$ for the minimum $\mathrm{k}_{\mathrm{y}}$. If this is the case, then the displacement hazard computed using the full logic tree will also be less than $\lambda^{*}$. Therefore, the full logic-tree analysis does not need to be performed for the identified grid cell. The screening analysis can be performed for all displacement thresholds. For larger displacement thresholds, more grid cells are excluded from the full logic-tree analysis. The screening analysis may remove as many as $70 \%$ to $90 \%$ of the grid cells from the full logictree analysis.

\subsection{ApPlication to Anchorage, Alaska Study Area}

Anchorage, Alaska was selected as the study area based on the history and occurrence of earthquakes and earthquake-induced slope failures, the availability of the required data in GIS 
format, and access to databases of soil properties in the study area. The availability of these data was due to the recently developed seismic landslide hazard maps for Anchorage by Jibson and Michael (2009).

\subsection{Topography and Shear Strength}

The Anchorage study area is about $301 \mathrm{~km}^{2}$ (Figure 6) and represents the extent of the recently developed seismic landslide hazard map by Jibson and Michael (2009). The central part of the study area consists of mostly plains with coastal bluffs along the shoreline, and the Chugach Mountains are found in the eastern part of the study area.

Slope information was obtained from a 2-m resolution DEM, resampled to $6 \mathrm{~m}$, that was derived from Light Detection and Ranging (LIDAR) produced by the Municipality of Anchorage in 2004 (Jibson and Michael 2009). The resulting slope map is shown in Figure 7a. Much of the study area consists of flat slopes of less than $10^{\circ}$, except for the coastal bluffs and the Chugach Mountains. The highest elevation is $1,026 \mathrm{~m}$ and the largest slope angle is $77^{\circ}$. About $1.0 \%$ of the study area is steeper than $30^{\circ}$ and about $4.6 \%$ of the area is steeper than $20^{\circ}$.

The shear strength parameters derived by Jibson and Michael (2009) were used in this study. Jibson and Michael (2009) used digitized versions of the surficial geologic maps of Schmoll and Dobrovolny (1972) and Yehle et al. (1992) and assigned shear strengths to each of the 17 geologic units across the study area using available geotechnical data (i.e., triaxial, direct shear, vane shear and standard penetration test (SPT) data). The geologic units are listed in Table 2 and the locations of these units are shown in Figure 7b. Sand and gravel units are characterized using effective (drained) shear strengths. Clays and silts are characterized using undrained shear strengths with zero friction angle. The assigned shear strengths are listed in 
Table 2. The shear strengths in Table 2 are considered best-estimates and are used as the mean properties upon which COV are applied.
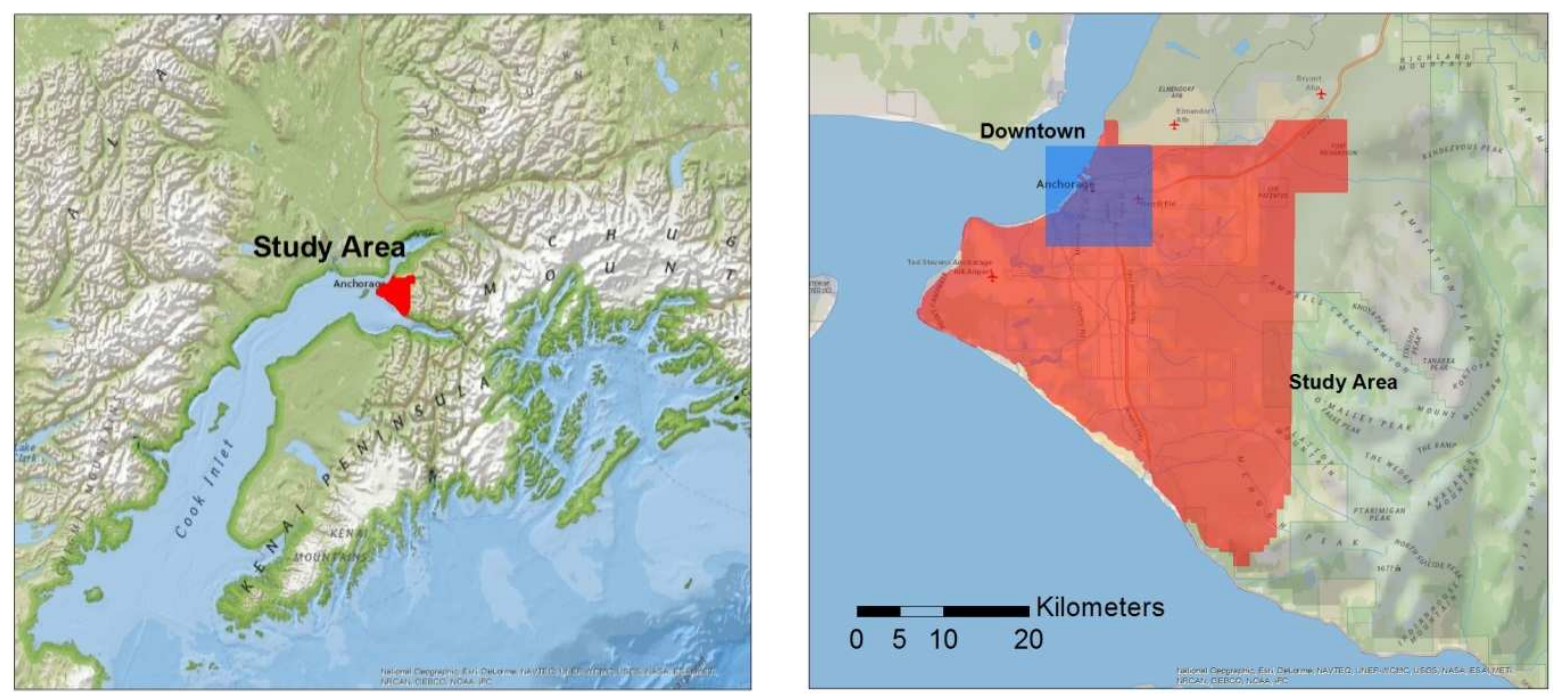

Figure 6. Overview of the study area in Anchorage, Alaska

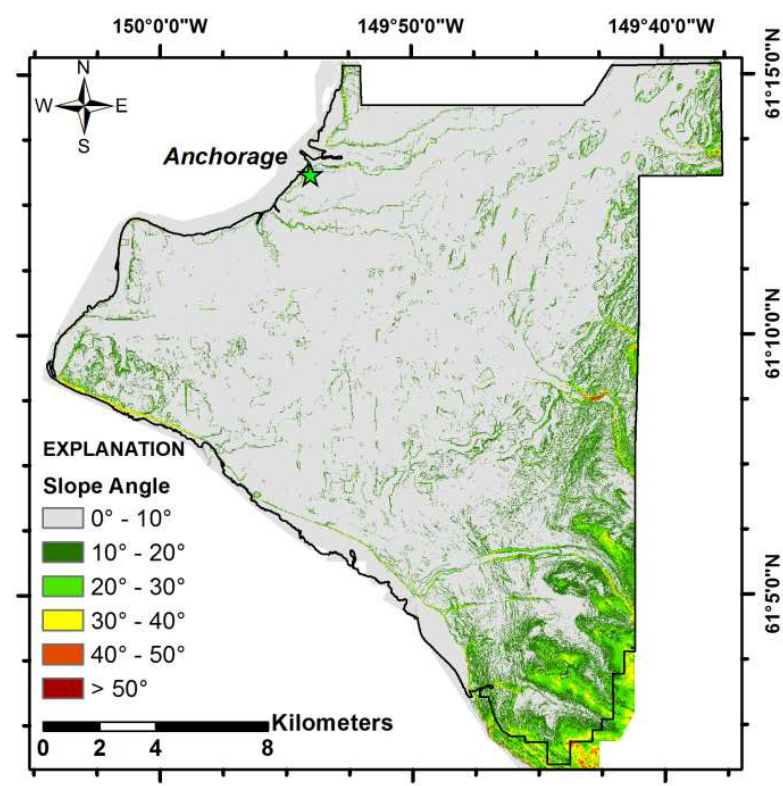

(a)

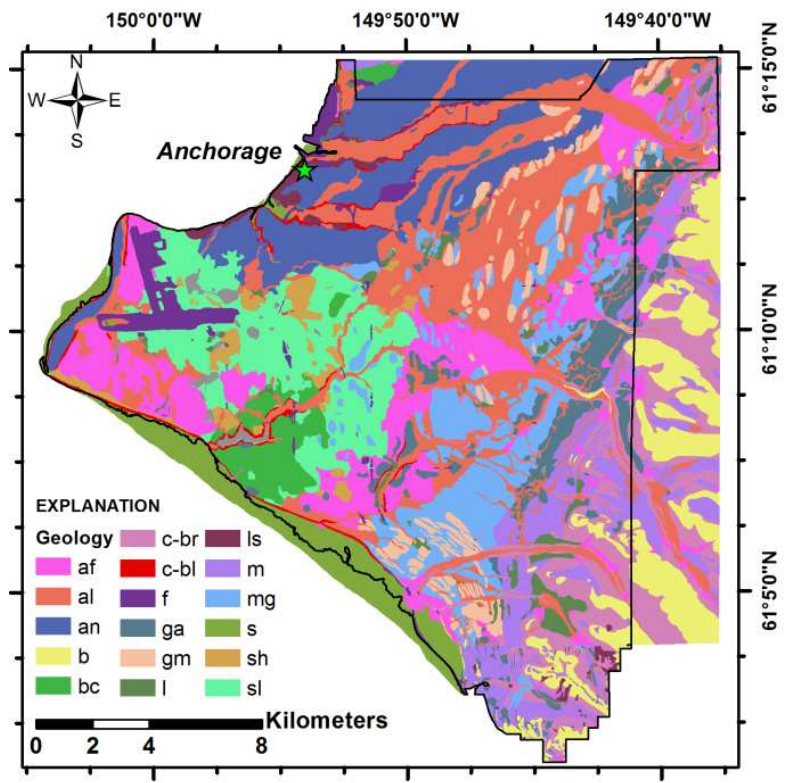

(b)

Figure 7. (a) Slope map and (b) surficial geologic map of Anchorage, Alaska. Geologic unit descriptions are provided in Table 2. 
Table 2. Geologic units and associated shear strengths for Anchorage, Alaska (Jibson and Michael 2009)

\begin{tabular}{|c|c|c|c|}
\hline Unit & $\begin{array}{c}\text { Friction } \\
\text { Angle (deg) }\end{array}$ & $\begin{array}{l}\text { Cohesion } \\
(\mathrm{kPa})\end{array}$ & Unit Description \\
\hline af & 36 & 24 & $\begin{array}{l}\text { Deposits in alluvial fans, alluvial cones, and emerged } \\
\text { deltas }\end{array}$ \\
\hline al & 36 & 19 & $\begin{array}{l}\text { Alluvium in abandoned stream channels and in terraces } \\
\text { along modern streams }\end{array}$ \\
\hline an & 36 & 24 & Coarse-grained surficial deposits \\
\hline $\mathrm{b}$ & 40 & 192 & Bedrock \\
\hline $\mathrm{bc}$ & 0 & 120 & Bootlegger Cove Clay \\
\hline c-br & 38 & 38 & $\begin{array}{l}\text { Colluvium derived from bedrock on slopes of the } \\
\text { Chugach Mountains }\end{array}$ \\
\hline c-bl & 0 & 38 & $\begin{array}{l}\text { Colluvium derived from glacial materials along coastal } \\
\text { bluffs }\end{array}$ \\
\hline $\mathrm{f}$ & 34 & 48 & Manmade fill \\
\hline ga & 32 & 38 & $\begin{array}{l}\text { Glacial alluvium in irregular-shaped hills (including } \\
\text { kames, eskers, and kame terraces) }\end{array}$ \\
\hline gm & 38 & 48 & $\begin{array}{c}\text { Glacial and (or) marine deposits, typically in elongate } \\
\text { hills }\end{array}$ \\
\hline 1 & 0 & 144 & Lake and pond deposits \\
\hline 1s & 30 & 24 & Landslide deposits, similar to an unit \\
\hline $\mathrm{m}$ & 38 & 43 & $\begin{array}{c}\text { Morainal deposits, generally in long ridges marking the } \\
\text { margins of former glaciers }\end{array}$ \\
\hline $\mathrm{mg}$ & 37 & 38 & Marine, glacial, and (or) lacustrine deposits \\
\hline S & 0 & 72 & Silt \\
\hline sh & 34 & 24 & $\begin{array}{l}\text { Sand deposits in broad, low hills, and windblown sand } \\
\text { deposits in cliffhead dunes near Point Campbell }\end{array}$ \\
\hline sl & 34 & 19 & $\begin{array}{c}\text { Sand deposits in a wide low-lying belt around Connors } \\
\text { Lake }\end{array}$ \\
\hline
\end{tabular}


It is important to note that Bootlegger Cove clay was responsible for significant deepseated landslides in Anchorage during the 1964 Great Alaska earthquake (Updike et al. 1984). These deep-seated failures are not well-represented by the infinite slope analysis used in regional seismic landslide analyses. Rather than trying to incorporate these deep-seated failure surfaces into the rigid sliding block procedure used here, Jibson and Michael (2009) identified areas prone to these failure separately from the sliding block analyses. Because the study presented here is focused on incorporating uncertainty in sliding block analyses for regional analysis, our results will not include these deep-seated failures.

\subsection{Development of Logic-Tree}

A three-part logic tree is developed for the Anchorage study area (Figure 8). The first two parts of the logic tree are related to the shear strength and sliding block properties, which influence the calculation of the yield acceleration, and the third part accounts for the epistemic uncertainty associated with the empirical displacement models.

The variability in shear strengths incorporated in the logic tree was guided by the study of Phoon and Kulhawy (1999). Phoon and Kulhawy (1999) noted that the coefficient of variation (COV, defined as the standard deviation divided by the mean) is about 10 to $50 \%$ for undrained shear strength and 5 to $15 \%$ for effective friction angle. For this study, the COV for the undrained shear strength is taken as $30 \%$, and for the effective friction angle it is taken as $10 \%$. The COV for the effective cohesion is taken as $20 \%$, so that the total uncertainty in the drained shear strength is similar to that for the undrained shear strength. These levels of uncertainty for shear strength were confirmed by Dr. Randall W. Jibson from the USGS (personal communication) based on practical experience and engineering judgment in Anchorage, Alaska. 


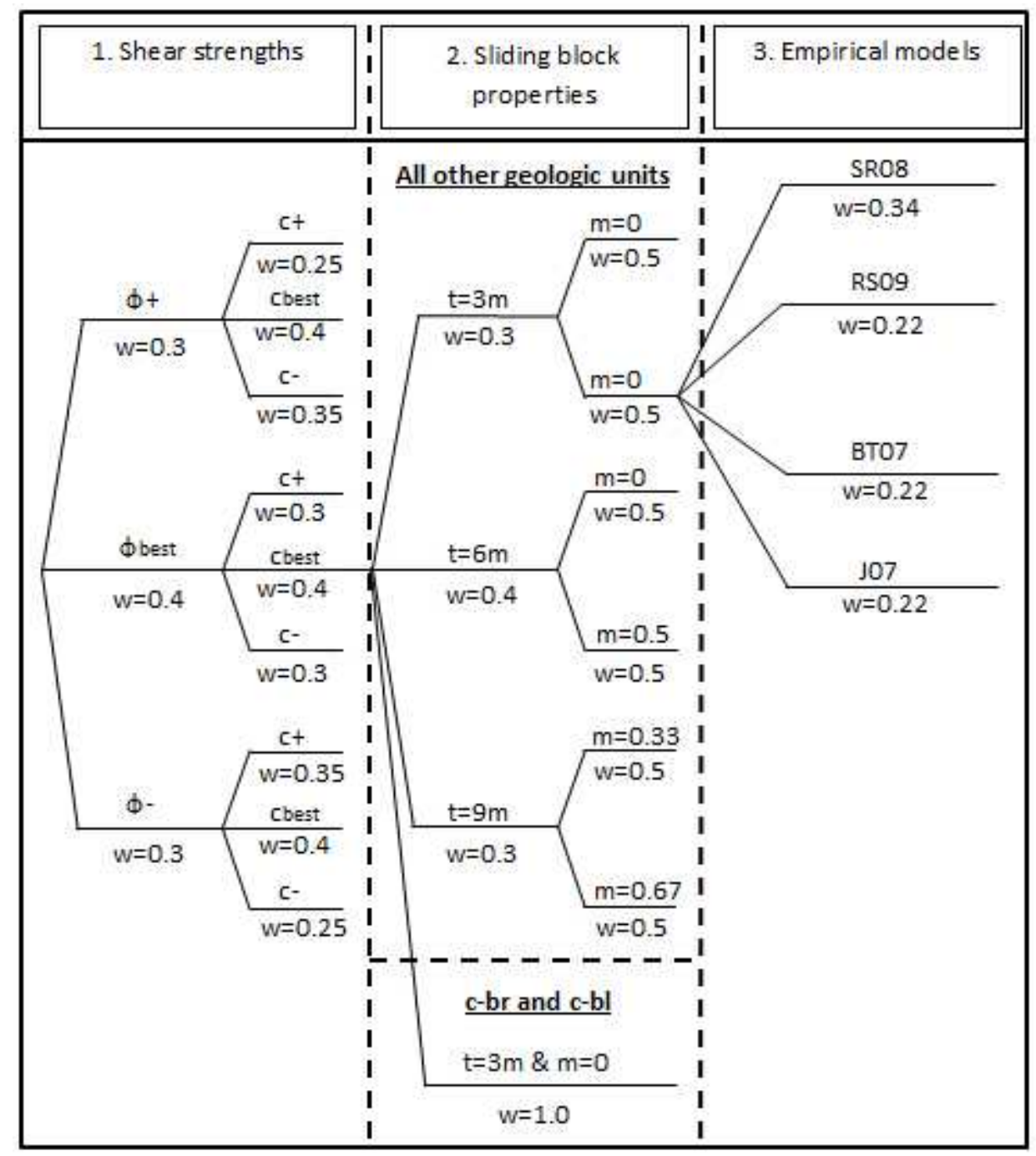

Figure 8. Logic tree for Anchorage Study Area

Assuming that the shear strength parameters follow a normal distribution and that the best-estimate values represent mean values, the COV along with the best-estimate shear strength parameters (Table 2) were used to define the standard deviation for each parameter. Within the logic tree, the shear strength parameters were modeled using a three point distribution (Keefer and Bodily 1983) that maintains the mean and standard deviation of the distribution. The high $(\phi+)$, mean $\left(\phi_{\text {best }}\right)$ and low $(\phi-)$ friction angles are taken as 10,50 , and 90 percentiles (i.e., $\mu$ $1.3 \sigma, \mu, \mu+1.3 \sigma$ ) with corresponding weights of $0.3,0.4$, and 0.3 . When assigning weights to 
the associated cohesion values $\left(\mathrm{c}^{+}, \mathrm{c}_{\text {best }}, \mathrm{c}^{-}\right)$, it is considered that the combinations of $\left(\mathrm{c}^{+}, \phi^{+}\right)$or $\left(\mathrm{c}^{-}, \phi^{-}\right)$are less likely than $\left(\mathrm{c}^{+}, \phi^{-}\right)$or $\left(\mathrm{c}^{-}, \phi^{+}\right)$due to negative correlation between $\mathrm{c}$ and $\phi$ (Cherubini 2000). Therefore, the weights for cohesion values associated with $\left(\mathrm{c}^{+}, \phi^{+}\right)$or $\left(\mathrm{c}^{-}, \phi^{-}\right)$ are taken as 0.25 and the weights for cohesion values associated with $\left(\mathrm{c}^{+}, \phi^{-}\right)$or $\left(\mathrm{c}^{-}, \phi^{+}\right)$are taken as 0.35 . The weight for the cohesion values associated with $\left(c_{\text {best }}, \varphi_{\text {best }}\right)$ is equal to 0.4 (Figure 8 ). Finally, it should be noted that the normal distribution is not the only statistical distribution that could be used to model the uncertainty in the soil properties. Other researchers have used the beta distribution (Refice and Capolongo 2002) and the log normal distribution (Toro 1995, Rathje et al. 2010).

The sliding block properties (Equation 1) include the thickness $(t)$ and the saturation percentage $(m)$. The thickness of the surficial geologic units, as described by Schmoll and Dobrovolny (1972) and Combellick (1999), was used to guide the selection of the best-estimate $t$ values (Wang 2014). This approach was taken because in most cases the underlying geologic unit is stronger than the surficial unit. Across all of the geologic units, except for the colluvium units (c-br and c-bl), the best-estimate $t$ value is $6 \mathrm{~m}$. Additional values of $3 \mathrm{~m}$ and $9 \mathrm{~m}$ are selected to represent the potential range of failure depths based on the range of thicknesses within each geologic units and based on engineering observations in Anchorage. The associated weights are 0.4 for the best-estimate $t$ and 0.3 for the others (Figure 8). Because the colluvium units exist as thin layers on the surface of slopes, their depths were taken as $3 \mathrm{~m}$ and no variability was included. The $m$ values were assigned based on two representative depths of the groundwater table in Anchorage, $3 \mathrm{~m}$ and $6 \mathrm{~m}$ (Jibson, personal communication,) and each was equally weighted. These depths are used with the corresponding thickness to assign the $m$ value (Figure 8). 
The epistemic uncertainty associated with the different empirical displacement models is incorporated in the logic tree using three displacement models that use PGA and M (Rathje and Saygili 2009, RS09;Bray and Travasarou 2007, BT07; and Jibson 2007, J07) and one vector displacement model that uses PGA and PGV (Saygili and Rathje 2008, SR08). The (PGA, M) models are equally weighted at 0.22 and the vector model is weighted at 0.34 . The vector model is more heavily weighted because the use of a second ground motion parameter provides a better estimate of sliding displacement. Using multiple empirical displacement models not only incorporates the epistemic uncertainty associated with the median predicted displacements, but also the epistemic uncertainty in the aleatory variability.

\subsection{Ground Motion Hazard}

The development of displacement hazard curves requires different ground motion hazard information for different displacement models. The (PGA, M) displacement models require a PGA hazard curve and associated magnitude disaggregrations, and the (PGA, PGV) model requires the joint annual probability of occurrence of PGA and PGV. The PGA hazard curve (Figure 9a) for Anchorage (N61.22, W149.90) was obtained from the 2008 USGS National Seismic Hazard Maps (http://geohazards.usgs.gov/hazardtool/) and is used across the study area. For the State of Alaska, seismic hazard deaggregation data from the USGS was published in 1998 but was not updated when the 2008 National Seismic Hazard maps were developed. The 1998 Alaska deaggregation only provides deaggregation data for 6 seismic hazard levels, ranging from $1 \%$ probability of exceedance in 50 years $(\lambda=0.00021 / \mathrm{yr}$ and PGA $=0.73 \mathrm{~g})$ to $50 \%$ probability of exceedance in 75 years $(\lambda=0.0091 / \mathrm{yr}$ and PGA $=0.21 \mathrm{~g})$. This range does not represent the entire seismic hazard curve, as shown in Figure 9a. To deal with the limited 
amount of deaggregation information, the deaggregation for hazard values outside the available range is assumed to be the same as for the closest hazard level. For example, the deaggregation for $\lambda=0.00021 / \mathrm{yr}$ is used for $\lambda<0.00021 / \mathrm{yr}$ and the deaggregation for $\lambda=0.0091 / \mathrm{yr}$ is used for $\lambda>0.0091 / \mathrm{yr}$.

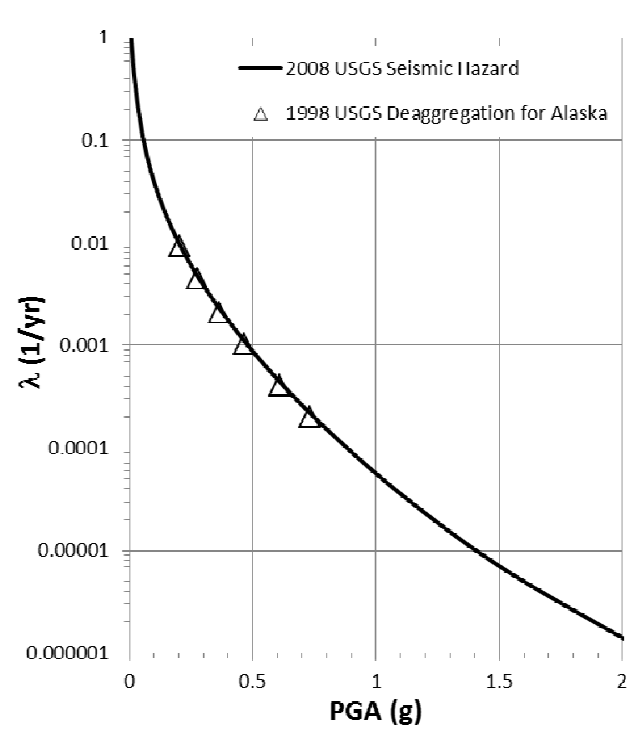

(a)

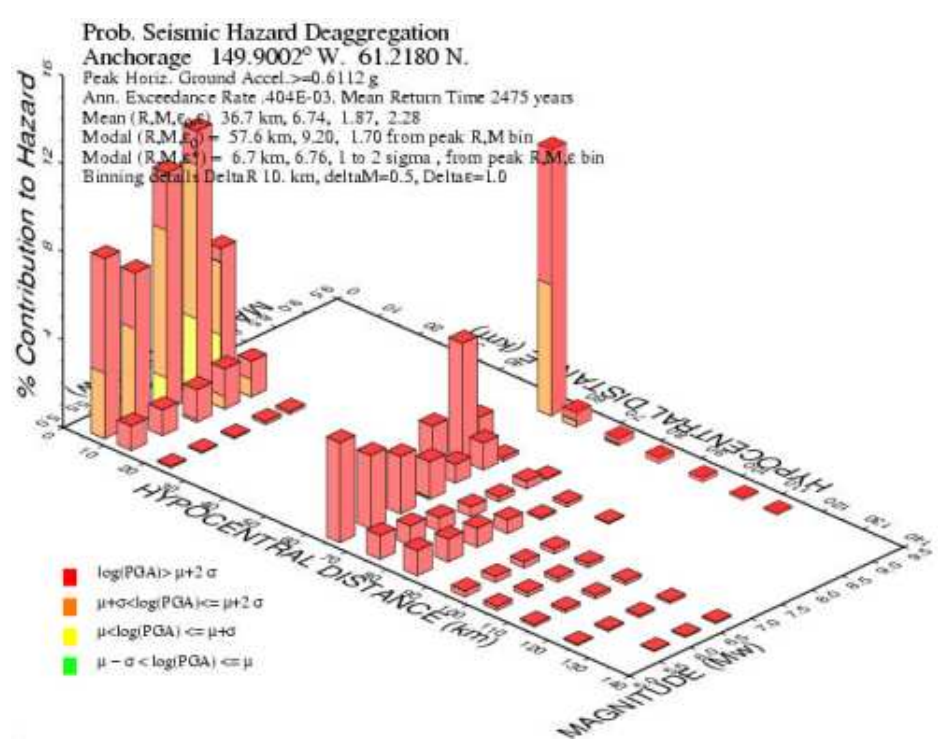

(b)

Figure 9. (a) PGA hazard curve and (b) seismic hazard deaggregation at $2 \%$ in 50 years for Anchorage, Alaska.

The 1998 seismic hazard deaggregation for the $2 \%$ in 50 year PGA in Anchorage is shown in Figure 9b. These data visually display the contributions of all magnitudes and distances to this ground motion level. The deaggregation clearly shows contributions from shallow crustal events at distances less than $20 \mathrm{~km}$ and from subduction events at distances greater than $60 \mathrm{~km}$. The deaggregations for each hazard level were used to derive the P[PGA, M] information required to compute the displacement hazard curves using Equation (3) for the (PGA, M) displacement models. The deaggregations along with the PGA hazard curve were used to derive the P[PGA, PGV] information required to compute the displacement hazard curves 
using Equation (4) for the (PGA, PGV) displacement model. In computing P[PGA, PGV], different ground motion prediction equations were used for shallow crustal events and subduction events, and distance of $50 \mathrm{~km}$ was used to distinguish the different events. Details regarding these computations can be found in Wang (2014). Figure 10 shows the P[PGA, M] and $\mathrm{P}[\mathrm{PGA}, \mathrm{PGV}]$ distributions for the Anchorage area. The $\mathrm{P}[\mathrm{PGA}, \mathrm{M}]$ distribution shows that the distribution of magnitudes associated with each PGA is relatively similar because the larger magnitude subduction events are further away and generate similar PGA as the smaller magnitude crustal events that are closer to Anchorage. The P[PGA, PGV] distribution shows that small PGA and large PGV are possible due to the large subduction events producing relatively small PGA with an associated larger PGV.

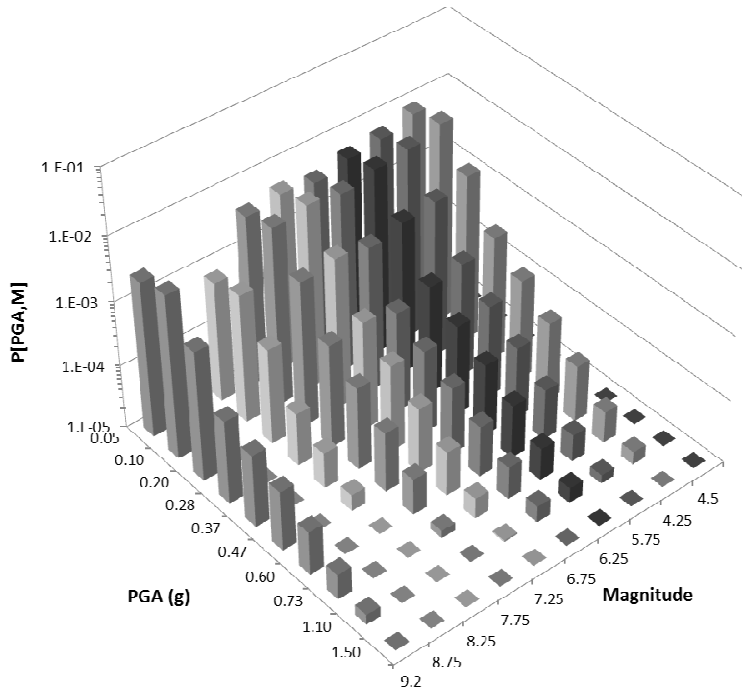

(a)

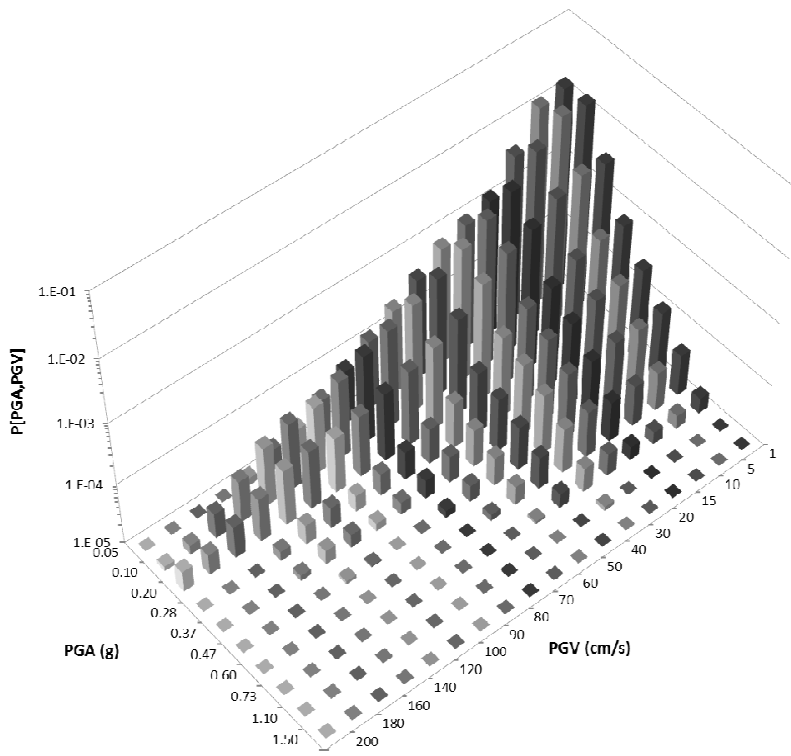

(b)

Figure 10. Ground motion hazard for use in developing displacement hazard curves: (a) joint annual probability of occurrence for PGA and M, (b) joint annual probability of occurrence for PGA and PGV 


\subsection{Seismic Landslide Hazard Map Results}

The Mean $\lambda_{\mathrm{D}}$ Threshold approach was used to generate probabilistic seismic landslide hazard maps for the Anchorage study area. Application of the Mean $\lambda_{\mathrm{D}}$ Threshold approach involved developing $\lambda_{\mathrm{D}}(\mathrm{x})$ vs. $\mathrm{k}_{\mathrm{y}}$ interpolation relationships for $\mathrm{x}=1,5$, and $15 \mathrm{~cm}$ and the four different empirical displacement models using the Anchorage ground motion hazard. These interpolation relationships were used with the $\mathrm{k}_{\mathrm{y}}$ values associated with the shear strength and sliding block sections of the logic tree (Figure 8 ) to compute $\overline{\lambda_{\mathrm{D}}}$ for each cell and assign it to the appropriate seismic landslide hazard category. These analyses were performed using Python codes running in ArcGIS®.

Figure 11 shows the resulting seismic landslide hazard map of Anchorage for a $2 \%$ probability of exceedance in 50 years $\left(\lambda^{*}=0.00041 / \mathrm{yr}\right)$. The area with moderate hazard $(1 \mathrm{~cm}$ $<\mathrm{D}<5 \mathrm{~cm}$, colored orange) and high hazard $(5 \mathrm{~cm}<\mathrm{D}<15 \mathrm{~cm}$, colored red) represent about $0.85 \%$ and $0.33 \%$ of the entire study area, respectively, and the area with very high hazard (D > $15 \mathrm{~cm}$, colored blue) covers $0.96 \%$ of the entire study area. Most areas with high or very high hazard are along coastal bluffs, stream valleys or in mountainous areas. In the downtown area (Figure 11b), colluvium and landslide deposits on slopes along coastal bluffs and stream valleys are most susceptible to seismic landslides. 


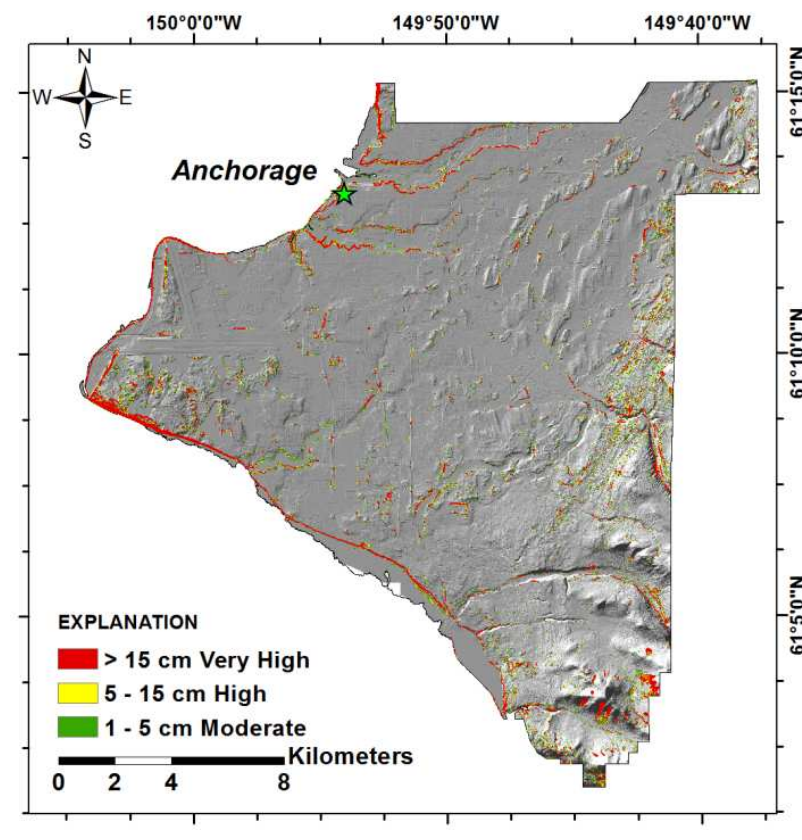

(a)

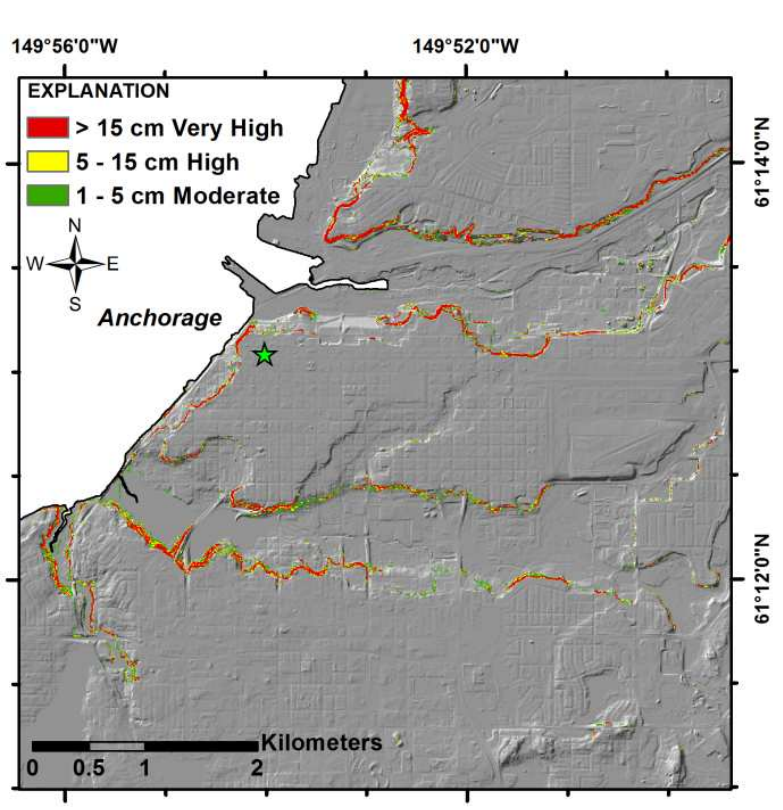

(b)

Figure 11. Probabilistic seismic landslide hazard map of Anchorage at 2\% probability of exceedance in 50 years (a) entire study area and (b) downtown area

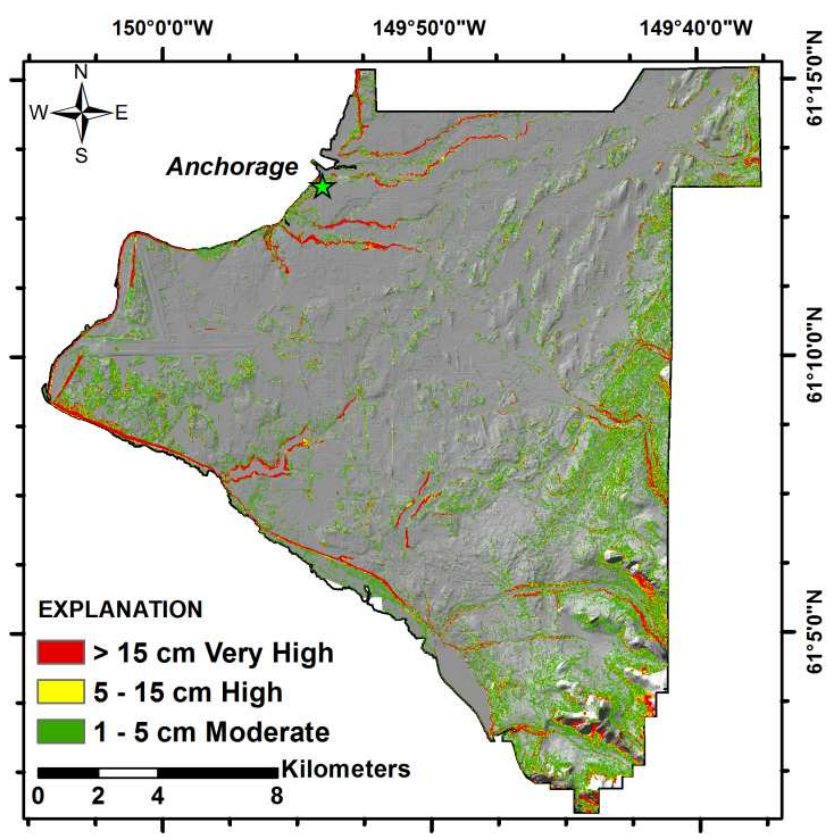

Figure 12. Deterministic seismic landslide hazard map of Anchorage at 2\% probability of exceedance in 50 years using slope parameters from Jibson and Michael (2009) 
The deterministic seismic landslide map developed using the procedures described by Jibson and Michael (2009) for the 2\% probability of exceedance in 50 year PGA is shown in Figure 12. The seismic landslide hazard in Figure 12 is significant, with $5.5 \%$ of the study area in the moderate category, $1.5 \%$ in the high category, and $2.7 \%$ in the very high category. Despite the fact that no aleatory variability and epistemic uncertainty were included in the Jibson and Michael (2009) map, these areas of seismic landslide hazard are 3 to 5 times larger than those developed in this study. The large seismic landslide hazard is a result of Jibson and Michael (2009) assuming unrealistic sliding block properties $(t=15 \mathrm{~m}$ and $m=0.8)$ for the colluvium units (c-bl, c-br), which are the units that contribute about $55 \%$ of the high/very high landslide cells in their study. These units exist as thin layers near the surface (Schmoll and Dobrovolny 1972, Combellick 1999) and thus failures cannot extend to a depth of $15 \mathrm{~m}$. The large $t$ and $m$ values result in smaller $\mathrm{k}_{\mathrm{y}}$ values that lead to more displacement and more hazard. This study used $t=3 \mathrm{~m}$ and $m=0.0$ to better represent the sliding block properties of these units (Figure 8). It is not uncommon to use overly conservative properties in seismic slope stability analyses, although it can lead to inflated estimates of seismic landslide potential. A logic tree formalizes the use of judgment and represents an alternative to using conservative input parameters. It allows one to incorporate a range of potential input parameters into an analysis and account for their effect on the seismic landslide assessment without being overly conservative.

Table 3 summarizes the distribution of the high/very high seismic landslide hazard (D > 5 $\mathrm{cm}$ ) among geologic units from this study and from Jibson and Michael (2009). The \% Study Area represents the percentage of the study area covered by each geologic unit, the \% Geo Unit is the percentage of grid cells with $\mathrm{D}>5 \mathrm{~cm}$ for each geologic unit, and the $\%$ Landslide Cells is 
the contribution of each geologic unit to all landslide cells in the study area. The geologic units that contribute significantly to the landslide hazard, either in terms of the percentage of total landslide cells or in terms of the percentage of the geologic unit identified as landslide cells, are highlighted in gray in Table 3.

With $35 \%$ of its area predicted as high/very high hazard, the colluvium unit c-bl is predicted to be most susceptible to landslides. This unit has the highest seismic landslide hazard because it has low undrained shear strength and mostly covers steeper coastal bluffs and valley walls (Figure 7). Jibson and Michael (2009) also showed that this unit has the highest landslide hazard, although their conservative sliding block properties resulted in $93 \%$ of the geologic unit placed in the high/very high hazard category. Landslide deposits (ls), mostly distributed on coastal bluffs, valley walls and the Chugach Mountains, also has a large portion of its area (about $15 \%$ ) classified as high/very high hazard. Other units with a large seismic landslide hazard are glacial alluvium (ga) and sand deposits in low hills (sh), although their percentages are much lower than for c-bl and ls. The other geologic units, which either have high shear strength underlain by stiff soil/rock (e.g. m, gm and mg) or which exist mostly on flat terrain (e.g. an, f and 1), do not represent a significant seismic landslide hazard. It is interesting that the colluvium unit in the mountainous area (c-br) was predicted as one of the most landslide-susceptible units by Jibson and Michael (2009), but it has almost no seismic landslide hazard in this study. This significant change in landslide hazard for this unit is due to the use of smaller values of sliding block thickness and saturation percentage used in this study $(t=3 \mathrm{~m}$ and $m=0.0$ vs. $t=15 \mathrm{~m}$ and $m=0.8$ in Jibson and Michael 2009), as discussed earlier. 
Table 3. Distribution of high/very high seismic landslide hazard areas across geologic units for $2 \%$ probability of exceedance in 50 years for Anchorage, Alaska

\begin{tabular}{|c|c|c|c|c|c|}
\hline \multirow[b]{3}{*}{ Geo Units } & \multirow[b]{3}{*}{$\begin{array}{c}\% \\
\text { Study Area }\end{array}$} & \multicolumn{4}{|c|}{ High/Very High Landslide Hazard Area } \\
\hline & & \multicolumn{2}{|c|}{ This Study } & \multicolumn{2}{|c|}{ Jibson and Michael (2009) } \\
\hline & & $\begin{array}{c}\% \\
\text { Geo Unit }\end{array}$ & $\begin{array}{c}\% \\
\text { Landslide Cells }\end{array}$ & $\begin{array}{c}\% \\
\text { Geo Unit }\end{array}$ & $\begin{array}{c}\% \\
\text { Landslide Cells }\end{array}$ \\
\hline af & $11.4 \%$ & $1.1 \%$ & $9.7 \%$ & $2.2 \%$ & $6.1 \%$ \\
\hline al & $22.0 \%$ & $0.6 \%$ & $10.5 \%$ & $1.3 \%$ & $7.0 \%$ \\
\hline an & $9.8 \%$ & $0.3 \%$ & $2.3 \%$ & $0.6 \%$ & $1.4 \%$ \\
\hline $\mathrm{b}$ & $2.2 \%$ & $0.0 \%$ & $0.0 \%$ & $0.4 \%$ & $0.2 \%$ \\
\hline $\mathrm{bc}$ & $2.8 \%$ & $1.3 \%$ & $2.8 \%$ & $1.9 \%$ & $1.2 \%$ \\
\hline c-br & $6.1 \%$ & $<0.1 \%$ & $0.1 \%$ & $18.9 \%$ & $27.4 \%$ \\
\hline c-bl & $1.3 \%$ & $34.7 \%$ & $34.0 \%$ & $93.0 \%$ & $28.2 \%$ \\
\hline $\mathrm{f}$ & $3.0 \%$ & $0.1 \%$ & $0.3 \%$ & $0.7 \%$ & $0.5 \%$ \\
\hline ga & $5.3 \%$ & $2.6 \%$ & $10.7 \%$ & $7.7 \%$ & $9.6 \%$ \\
\hline gm & $3.9 \%$ & $0.2 \%$ & $0.5 \%$ & $0.9 \%$ & $0.8 \%$ \\
\hline 1 & $1.8 \%$ & $0.3 \%$ & $0.4 \%$ & $0.7 \%$ & $0.3 \%$ \\
\hline ls & $1.0 \%$ & $15.0 \%$ & $12.1 \%$ & $22.4 \%$ & $5.6 \%$ \\
\hline $\mathrm{m}$ & $6.0 \%$ & $0.7 \%$ & $3.0 \%$ & $3.0 \%$ & $4.2 \%$ \\
\hline $\mathrm{mg}$ & $9.5 \%$ & $0.2 \%$ & $1.5 \%$ & $0.8 \%$ & $1.8 \%$ \\
\hline $\mathrm{s}$ & $2.0 \%$ & $1.8 \%$ & $2.7 \%$ & $2.8 \%$ & $1.4 \%$ \\
\hline sh & $2.1 \%$ & $4.2 \%$ & $6.8 \%$ & $5.8 \%$ & $3.0 \%$ \\
\hline sl & $10.0 \%$ & $0.3 \%$ & $2.4 \%$ & $0.5 \%$ & $1.3 \%$ \\
\hline
\end{tabular}


To investigate the influence of each part of the logic tree on the seismic landslide hazard, a series of analyses was performed using different parts of the logic tree (i.e., shear strength, sliding block properties, and both the shear strength and sliding block properties). For these analyses, the percentage of the study area exceeding the $5 \mathrm{~cm}$ displacement threshold (i.e., high and very high hazard) was compiled and is summarized in Figure 13. Also analyzed is the deterministic approach in which the $2 \%$ in 50 year PGA was used to compute the median sliding displacement. This deterministic approach is essentially the approach used by Jibson and Michael (2009), but here the assumed sliding block properties are assigned using the bestestimate values from the logic tree (Figure 8) rather than the conservative approach used by Jibson and Michael (2009).

As seen in Figure 13, the area of high/very high hazard increases from $0.37 \%$ for the deterministic approach (Case 1) to $0.49 \%$ for the probabilistic approach (Case 2). Both of these analyses do not include a logic tree and thus the increase is due solely to accounting for aleatory variability in the displacement prediction. The area of high/very high hazard increases further as the different components of the logic tree are introduced (Cases 3, 4, and 5). The influence of the epistemic uncertainty in the shear strengths (Case 3) is similar to the influence of the epistemic uncertainty in the sliding block properties (Case 4), although this may not always be the case. When both of these sources of epistemic uncertainty are included (Case 5), the total area of high/very high landslide hazard is 3.5 times larger than for the deterministic case. This result may seem counter to that observed when comparing the probabilistic results in Figure 11 with the deterministic results from Jibson and Michael (2009) in Figure 12. But an important distinction is that different best-estimate properties were used in the analyses for Figures 11 and 
12 and these differences are the reason for the significant differences in the landslide hazards shown in Figures 11 and 12.

The examples in Figure 13 demonstrate how epistemic uncertainty increases the seismic landslide hazard relative to the landslide hazard for the baseline properties of the logic tree. This effect is observed for ground motion hazard studies as well (Bommer and Scherbaum 2008) and is an important effect that provides incentive to reduce epistemic uncertainties wherever possible because investing in the collection of additional data that reduce uncertainties can lead to reduced landslide hazard estimates. Approaches that do not acknowledge and account for these epistemic uncertainties cannot provide the same incentive for investment in data collection.

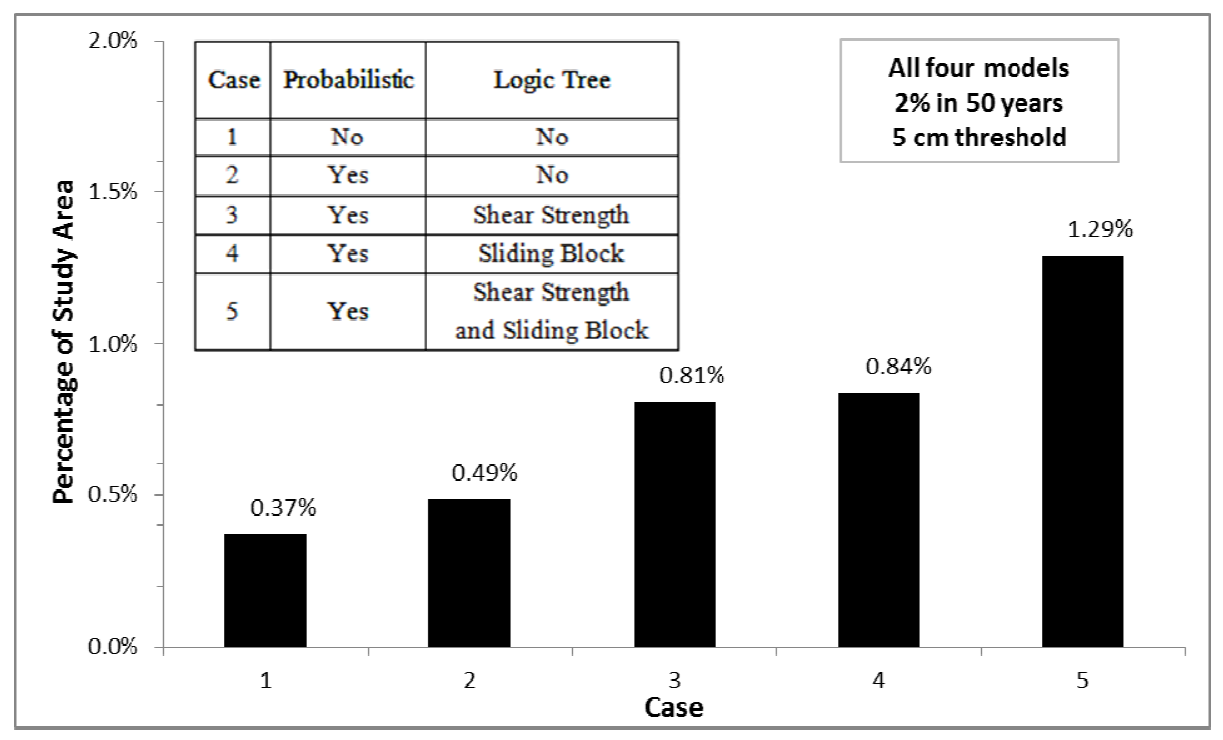

Figure 13. The influence of different segments of the logic tree on the computed high/very high seismic landslide hazard at $2 \%$ probability of exceedance in 50 years

\subsection{CONCLUSIONS}

Logic-tree analysis allows for the epistemic uncertainties in the slope properties and among empirical displacement models to be incorporated into seismic landslide hazard mapping. This paper describes a probabilistic approach to developing seismic landslide hazard maps that includes a logic-tree analysis to compute a weighted mean displacement hazard curve from the 
branches of a logic tree. This paper also describes the Mean $\lambda_{\mathrm{D}}$ Threshold approach to efficiently computing the weighted mean displacement hazard curve, which is useful when applying logictree analysis to regional studies.

The proposed probabilistic approach is applied to a study area in Anchorage, Alaska to develop seismic landslide hazard maps. In applying this probabilistic approach to Anchorage, the area associated with high/very high hazard was increased relative to a deterministic approach by more than a factor of 3 when the epistemic uncertainties associated with the soil/slope properties and empirical displacement models were taken into account. However, comparison with a previously published deterministic seismic landslide map indicates that the probabilistic approach predicts a smaller seismic landslide hazard. This result is due to the deterministic map using conservatively large values of the thickness of the sliding block, which were particularly unrealistic for the colluvium units that are only a few meters thick. The logic-tree approach provides an alternative and formal approach to account rigorously for uncertainties in the soil/slope properties, and it can avoid using overly conservative input parameters to capture these uncertainties in a deterministic approach.

The probabilistic approach described in this paper addresses important issues in regional seismic landslide mapping related to uncertainties. However, the approach does not tackle other important issues that affect the accuracy of seismic landslide maps, such as the spatial variability of soil properties within a geologic unit and topographic amplification of ground shaking (Dreyfus et al. 2013). Developing techniques that can incorporate these effects on a regional scale would considerably improve the predictive ability of seismic landslide hazard maps. 


\subsection{ACKNOWLEDGMENTS}

Technical discussions with Dr. Randall M. Jibson of the USGS were very beneficial and gratefully acknowledged. Financial support for this work was provided by the USGS, Department of the Interior, under grant G12AP20083. The views and conclusions contained in this document are those of the authors and should not be interpreted as necessarily representing the official policies, either expressed or implied, of the U.S. Government.

\subsection{REFERENCES}

Baker, J. W. (2007). Correlation of ground motion intensity parameters used for predicting structural and geotechnical response. 10th international conference on applications of statistics and probability in civil engineering. Tokyo, Japan.

Bazzurro, P. (1998). Probabilistic seismic demand analysis. Doctoral Dissertation, Stanford University, Stanford, CA.

Bazzurro, P. and Cornell, C. A. (2002). Vector-valued probabilistic seismic hazard analysis. Proceedings, 7th U.S. National Conference on Earthquake Engineering, Boston, MA. 10 p.

Bommer, J. J., and Scherbaum, F. (2008). The use and misuse of logic trees in probabilistic seismic hazard analysis, Earthquake Spectra, 24(4), 997-1009.

Bradley, B. A. (2010). A generalized conditional intensity measure approach and holistic ground motion selection. Earthquake Engineering and Structural Dynamics, 39(12), 1321-1342.

Bray, J. D. and Travasarou, T. (2007). Simplified procedure for estimating earthquake-induced deviatoric slope displacements. J. Geotech. Geoenviron. Eng., 133(4), 381-392.

Cherubini, C. (2000). Reliability evaluation of shallow foundation bearing capacity on c', $\square$ ' soils, Can. Geotech. J., 37, 264-269

Combellick, R. A. (1999). Simplified geologic map and cross sections of central and east Anchorage, Alaska. Alaska Division of Geological and Geophysical Surveys Preliminary Interpretive Report 1999-1, scale 1:25,000.

Dreyfus, D. Rathje, E., and Jibson, R. 2013. "The influence of different simplified sliding-block models and input parameters on regional predictions of seismic landslides triggered by the Northridge earthquake," Engineering Geology, 163, 41-54, doi:10.1016/j.enggeo.2013.05.015.

Jibson, R. W. (2007). Regression models for estimating coseismic landslide displacement. Engineering Geology, 91(2007), 209-218. 
Jibson, R. W. (2011). Methods for assessing the stability of slopes during earthquakes-A retrospective. Engineering Geology, 122(2011), 43-50.

Jibson, R. W. and Michael, J. A. (2009). Maps showing seismic landslide hazards in Anchorage, Alaska: U.S. Geoᄀlogical Survey Scientific Investigations Map 3077, scale 1:25,000, 11p. pamphlet. [Available at URL http://pubs.usgs.gov/sim/3077]

Jibson, R. W., Harp, E. L., and Michael, J. A. (2000). A method for producing digital probabilistic seismic landslide hazard maps. Engineering Geology, 58(2000), 271-289.

Keefer, D. K. (2002). Investigating landslides caused by earthquakes - a historical review. Surveys in Geophysics, 23, 473-510.

Keefer, D.L. and Bodily S.E. (1983). Three Point Approximations for Continuous Random Variables.Management Science, 595-609.

McCrink, T. P. (2001). Regional earthquake-induced landslide mapping using Newmark displacement criteria, Santa Cruz County, California. In H. Ferriz, \& R. Anderson (Eds.). Engineering Geology Practice in Northern California. California Division of Mines and Geology Bulletin 210 / Association of Engineering Geologists Special Publication 12, 77 92.

Newmark, N. (1965). Effects of earthquakes on dams and embankments. Geotechnique, 15(2), 139-160.

Petersen, M. D., Frankel, A. D., Harmsen, S. C., Mueller, C. S., Haller, K. M., Wheeler, R. L., Wesson, R. L., Zeng, Y., Boyd, O. S., Perkins, D. M., Luco, N., Field, E. H., Wills, C. J., and Rukstales K.S. (2008). Documentation for the 2008 Update of the United States National Seismic Hazard Maps. U.S. Geological Survey Open-File Report 2008-1128.

Phoon, K. K. and Kulhawy, F. H. (1999). Characterization of geotechnical variability. Can. Geotech. J., 36, 612-624.

Rathje, E. M. and Saygili, G. (2008). Probabilistic seismic hazard analysis for the sliding displacement of slopes: scalar and vector approaches. J. Geotech. Geoenviron. Eng., ASCE, 134(6), 804-814.

Rathje, E. M. and Saygili, G. (2009). Probabilistic assessment of earthquake-induced sliding displacements of natural slopes. Bulletin of the New Zealand Society for Earthquake Engineering, 42(1), 18-27.

Rathje, E.M., Kottke, A.R. and Trent, W.L. (2010). "The Influence of Input Motion and Site Property Uncertainties on Seismic Site Response Analyses," Journal of Geotechnical and Geoenvironmental Engineering, ASCE, 136(4), 607-619.

Refice, A. and Capolongo, D. (2002). Probabilistic modeling of uncertainties in earthquakeinduced landslide hazard assessment. Computers \& Geosciences, 28(2002), 735-749

Saygili, G. and Rathje, E. M. (2008). Empirical predictive models for earthquake-Induced sliding displacements of slopes. J. Geotech. Geoenviron. Eng., 134(6), 790-803.

Saygili, G. and Rathje, E. M. (2009). Probabilistically based seismic landslide hazard maps: An application in Southern California. Engineering Geology, 109(2009), 183-194. 
Schmoll, H. R. and Dobrovolny, E. (1972). Generalized geologic map of Anchorage and vicinity, Alaska. U.S. Geological Survey Miscellaneous Investigation Map I-787-A, scale $1: 24,000$.

Toro, G. R. (1995). Probabilistic models of site velocity profiles for generic and site-specific ground-motion amplification studies, Technical Report 779574, Brookhaven National Laboratory, Upton, New York.

Updike, R. G., Egan, J. A., Moriwaki, Y., Idriss, I. M., and Moses, T. L. (1988). A model for earthquake-induced translatory landslides in Quaternary sediments: Geological Society of America Bulletin, 100(5), 783-792.

Wang Y. and Rathje E. M. (2014). Incorporating epistemic uncertainties into regional seismic landslide maps. Proceedings of the 10th National Conference in Earthquake Engineering, Earthquake Engineering Research Institute, Anchorage, AK, 2014.

Wang. Y. (2014). Probabilistic assessments of the seismic stability of slopes: improvements to site-specific and regional analyses. Doctoral Dissertation, University of Texas at Austin, Austin, TX.

Yehle, L. A., Schmoll, H. R., and Dobrovolny, E. (1992). Surficial geologic map of the Anchorage A-8 SE quadrangle, Alaska. U.S. Geological Survey Open-File Report 92350 , scale 1:25,000. 